\title{
Can Micro-Credit Promote Financial Inclusion? The Evidence from China
}

\author{
Jianhua Yi ${ }^{1}$, Ran Zhang ${ }^{2 *}$, Feng Guo ${ }^{3}$ \\ ${ }^{1}$ University of Jinan, Jinan, China \\ ${ }^{2}$ Shandong University, Shandong Communication and Media College, Jinan, China \\ ${ }^{3}$ The People's Bank of China, Jinan, China \\ Email:610128457@qq.com, *july0731@163.com, guofeng1108@126.com
}

How to cite this paper: Yi, J. H., Zhang, R., \& Guo, F. (2018). Can Micro-Credit Promote Financial Inclusion? The Evidence from China. Journal of Financial Risk Management, 7, 428-441. https://doi.org/10.4236/jfrm.2018.74023

Received: April 5, 2018

Accepted: December 23, 2018

Published: December 26, 2018

Copyright (c) 2018 by authors and Scientific Research Publishing Inc. This work is licensed under the Creative Commons Attribution International License (CC BY 4.0).

http://creativecommons.org/licenses/by/4.0/

\begin{abstract}
This paper offers an analysis of the effect of micro-credit to financial inclusion. We use the survey data of Shandong Province in China since 2010 to 2016, and measure the index of financial inclusion to build the sample for empirical study. This paper examines the role of micro-credit for enlarging the coverage of financial service and decreasing the financial cost. Finally, we give the evidence that the development of micro-credit has the positive effect on promoting the financial inclusion.
\end{abstract}

\section{Keywords}

Financial Inclusion, Micro-Credit, Index of Financial Inclusion

\section{Introduction}

Financial inclusion, defined as the use of formal financial service for all sectors of society at the affordable cost (Allen et al., 2016), increasingly becomes a popular research field that attracts wide attention from academia, government, and industry. During the 2016 G20 summit, G20 leaders and scholars made great efforts trying to meet the challenge of promoting the financial inclusion around the world (GPFI, 2015), especially to guide the developing countries to relieve the financial exclusion and improve the effect of financial service. In theory, it is crucial for those in the developing countries who are financially excluded to receive necessary financial services. This will significantly increase their ability of financing and investment and improve their economic situation through financial activities. Such an arrangement also contributes to poverty reduction and economic growth in these countries (Bruhn \& Love, 2014). In practice, the development of inclusive finance includes not only the access to various financial 
services at a reasonable cost for all individuals but also the expansion of the coverage of financial service through providing transparent regulations on financial institutions (Levine, 1999; Beck et al. 2007).

In the past decades, many scholars studied financial exclusion and found that financial exclusion led to the lack of basic financial services and became an important cause of poverty. For instance, the lack of bank accounts makes liquidity management and payment difficult, which causes a high fee level associated with the use of money order or other cash services (Lusardi, 2010); alienated from banks and unable to get formal financial service, individuals in low income regions have to borrow from informal organizations and undertake higher rates of interest (Jones, 2001; Palmer \& Conaty, 2002); the lack of financial institutions aggravates the gap between the supply of and the demand for basic financial service and raises the entry threshold of market to low income individuals (Branch \& Cifuentes, 2001; Jones, 2006). To solve these problems, many countries made efforts to design a new type of financial intermediary which provides micro-credit to meet the financial needs of the poor, for example, the local community unions which were established by hundreds of volunteers in Britain (Jones, 1999). Supported by government policies and public grants, micro-credit expanded rapidly and brought positive effects to the low-income individuals during the 1980s and 1990s; however, the effects in recent years are not as apparent as before. Some scholars found a very limited effect of micro-credit on low income communities. Some even claimed that the new financial intermediary was doom to a failure (Dayson et al., 2001; Mckillop et al., 2007). From this perspective, microfinance institutions may produce positive effects in increasing the coverage of financial services, but the effects may not be persistent. Relying on microfinance institutions cannot completely resolve the problem of financial exclusion and narrow the gap between the rich and the poor.

The development of inclusive finance has the potential to solve the problem of financial exclusion and, hence, the poverty; but the drawbacks are also obvious. If micro-credit can promote the development of inclusive finance and increase the inclusiveness of regional financial system, it should be included in the "Inclusive Financial System". With this background, the research question of this paper is two-fold: 1) construct the Financial Inclusion Index (FII) according to the intrinsic requirement of inclusive finance, taking into account both the coverage of financial service and the cost of financial service; and 2) conduct an empirical analysis on the effects of micro-credit on the regional development of inclusive finance.

This paper is primarily based on the survey data of Shandong Province in China due to the following reasons. First, China is the largest developing economy with a big gap between rich and poor in the world. The problem of financial exclusion in some areas is more prominent. In recent years, China has made some important progress in the development of micro-credit and inclusive financial institutions and therefore becomes an ideal case of study. Second, China has not established a systematic statistical database that covers key variables such 
as account information, distribution of financial institutions, and interest rates charged by informal financing. Quantitative analysis for all Chinese provinces is not feasible. One possible way out is to focus on the representative provinces, which can mimic the average situation of the whole country in industrial structure, financial development level, population structure, etc. Following these criteria, Shandong Province is an appropriate pick.

The remainder of this paper is structured as follows. Section 2 describes our data and methodology for constructing the IFI. Section 3 presents the empirical analyses on the effects of micro-credit on financial inclusion. Section 4 concludes.

\section{Methodology for Measuring the Index of Financial Inclusion}

\subsection{Methodology}

Inclusive financial system contains several dimensions. We follow a multidimensional approach to construct the index of financial inclusion (IFI). Our approach is similar to the one used by UNDP for computation of some well-known development indexes such as the HDI and the $\mathrm{HPI}^{1}$. As in the case of these indexes, we first calculate a sub-index index for each dimension of financial inclusion. For example, the dimension index for the ith dimension $k_{i}$, is computed by the following equation

$$
k_{i}=\lambda_{i}\left(A_{i}-m_{i}\right) /\left(M_{i}-m_{i}\right)
$$

where $A_{i}$ is the actual value of dimension $i, M_{i}$ is the upper limit of the value of dimension $i$, and $m_{i}$ is the lower limit of the value of dimension $i . \quad \lambda_{i}$ is the weight attached to dimension I, which can be computed by Equation (2)

$$
\lambda_{i}=\left(\sigma_{i} / \bar{A}_{i}\right) / \sum_{i=1}^{n}\left(\sigma_{i} / \bar{A}_{i}\right)
$$

where $\sigma_{i}$ is the standard deviation of dimension $i$ and $A_{i}$ is the mean of dimension $i$. Equation (1) implies that $0 \leq k_{i} \leq \lambda_{i}$. The higher the value of $k$, the more progress made on dimension $i$. Suppose we consider $\mathrm{n}$ dimensions of financial inclusion, then an overall state of financial inclusion can be represented by a point $K_{i}=\left(K_{1}, K_{2}, \cdots K_{n}\right)$ on the n-dimensional Cartesian space. In this space, the point $O=(0,0, \cdots 0)$ represents the worst situation of financial inclusion while the point $\Lambda=\left(\lambda_{1}, \lambda_{2} \cdots \lambda_{n}\right)$ represents the best situation. Then the IFI can be calculated by the normalized inverse Euclidean distance of the point $K$ from point $\Lambda=\left(\lambda_{1}, \lambda_{2} \cdots \lambda_{n}\right)$. The exact formula is

$$
I F I_{i}=1-\frac{\sqrt{\left(w_{1}-d_{1}\right)^{2}+\left(w_{2}-d_{2}\right)^{2}+\cdots+\left(w_{n}-d_{n}\right)^{2}}}{\sqrt{\left(w_{1}^{2}+w_{2}^{2}+\cdots+w_{n}^{2}\right)}}
$$

The IFI defined above can then be used to measure financial inclusion on different levels of economic aggregation during different time periods.

${ }^{1}$ UNDP's Human Development Reports (http://www.undp.org/). 


\subsection{Indicators}

To the best of our knowledge, there has not been an universally recognized system of indicators for the development of financial inclusion. Many research institutions, including Finscope, AFI and World Bank ${ }^{2}$ have established their own indicator system according to the definition of financial inclusion. Based on their studies (Vighneswara, 2014; Allen et al. 2016; GPFI, 2015), this paper selects 11 indicators that reflect information concerning the distribution of financial institutions ${ }^{3}$, account usage, small business loan, and financing costs to establish the core set of Financial Inclusion Indicators. The number of bank branches, POS machines, ATM, and accounts are selected to measure the coverage of financial services; the loan interest rate of small and micro enterprises, the loan interest rate of agriculture-related loans, and the interest rate of informal finance are selected to reflect the cost of financial service and establish the cost index of financial service. Other indicators are selected to reflect the application of the loan, and the development of the Macro-economy and finance.

\subsection{Data}

We have constantly performed an annual survey for more than 300 micro-credit organizations in all 17 prefectures of Shandong province since $2009^{4}$. During this period, the research team of this paper has conducted the continuous tracking of all the micro-credit organizations every year and acquired its operation data quarterly. Indicators in Table 1 are taken from the official reports and statements published by every financial management department and our survey. Since a large number of county data in the sample period are missing or not disclosed, the research team calculated them based on the balance sheet and income statements to ensure the sample be complete and continuity. Table 2 presents the descriptive statistics of all indicators involved in Table 1 during our sample period of 2010-2016.

\subsection{Result of IFI}

Making use of the methodology introduced before, we calculated the annual IFI for all 17 prefectures in Shandong province during 2010-2016 and constructed

${ }^{2}$ In recent years, research institutions, such as Finscope, AFI and World Bank have all put forward their own core set of Financial Inclusion Indicators, of which, Finscope focuses more on the distribution situation of financial service in different populations, while the designed indicators on account use, financial institution distribution and loan distribution, etc. of AFI and World Bank is more detailed.

${ }^{3}$ In China, the main purpose of promoting the financial inclusion is to provide more financial service to micro businesses and rural economy. Considering the dominant role of indirect financing market, we choose the 4 main indicators (bank branches, POS machines, ATM, and accounts) to reflect the availability on financial service in country area, hoose 3 indicators on different interest rates to reflect the cost of the service on micro businesses and rural economy. Finanlly, Following the studies (Sadhan, 2011; Zuzana \& Laurent 2015), we choose the other 4 indicators to reflect the application of the loan, Macro-economy and finance.

${ }^{4}$ Affected by opening and closing down, the number of micro-credit organizations in our sample changes each year. For example, there were 421 micro-credit organizations in 2015, 21 more than 2014. 
Table 1. Financial inclusion indicator system.

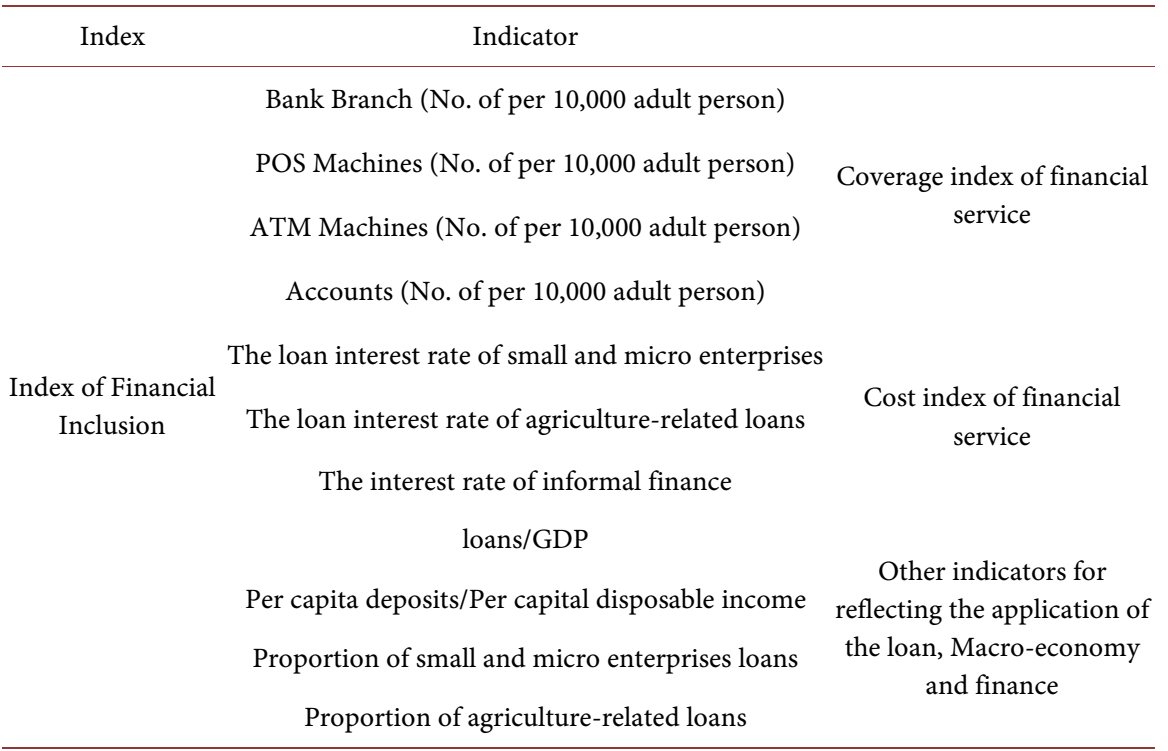

the Coverage index of financial service and Cost index of financial service based on the nature of financial inclusion. Table 3 presents the result of the three indexes.

It can be seen from Table 3 that the development of financial inclusion in all 17 prefectures is steadily improving after 2009. Out of all 17 prefectures, 16 prefectures observed a rising IFI year by year; meanwhile, the IFI of most prefectures increased significantly in 2011 and 2012 and reached the maximum value in 2016. Among the 17 prefectures, the growth rate of IFI in Jinan and Qingdao is relatively stable over time; these two prefectures happen to be among the most developed regions of Shandong province. We also observe relatively unstable growth rate of IFI over time in some less developed regions. This comparison suggests apparent differences across regions despite the overall development of financial inclusion in Shandong province.

\section{The Impact of Micro-Credit on the Inclusive Finance}

\subsection{Model}

To accurately study the influence of micro-credit on inclusive finance in each prefecture and mitigate the impacts of unobserved variables, this paper adopts the panel data model. Since this paper established the IFI at the prefecture level, for each year, we take the simple average of all micro-credit organizations within a prefecture to reflect the overall performance of this prefecture. All variables related to the micro-credit organizations are treated in this way. The major regression model I is specified as:

$$
\begin{gathered}
\qquad \operatorname{IFDI}_{i}=\alpha+\beta_{i} T_{i t}+u_{i}+\varepsilon_{i t} \\
T_{i t}=\left(\text { corporate, } \Delta \text { capital }, \Delta \text { loan }, r_{\text {loan }}, \Delta \text { custom, } R_{N P L s}, g_{\text {profit }}, P_{\text {loan }}<50\right)_{i t}
\end{gathered}
$$


Table 2. The statistics of all indicators (2010-2016).

\begin{tabular}{|c|c|c|c|c|c|c|c|c|c|c|c|c|}
\hline & & $\begin{array}{c}\text { Bank } \\
\text { Branch }\end{array}$ & $\begin{array}{c}\text { POS } \\
\text { Machines }\end{array}$ & $\begin{array}{c}\text { ATM } \\
\text { Machines }\end{array}$ & Accounts & Loans/GDP & $\begin{array}{c}\text { Per capita } \\
\text { deposits/Per } \\
\text { capital } \\
\text { disposable } \\
\text { income }\end{array}$ & $\begin{array}{c}\text { Proportion } \\
\text { of small and } \\
\text { micro } \\
\text { enterprises } \\
\text { loans }\end{array}$ & $\begin{array}{l}\text { Proportion } \\
\text { of } \\
\text { agriculture } \\
\text { related } \\
\text { loans }\end{array}$ & $\begin{array}{c}\text { The loan } \\
\text { interest rate } \\
\text { of small and } \\
\text { micro } \\
\text { enterprises }\end{array}$ & $\begin{array}{c}\text { The loan } \\
\text { interest rate } \\
\text { of } \\
\text { agriculture } \\
\text { related } \\
\text { loans }\end{array}$ & $\begin{array}{c}\text { The interest } \\
\text { rate of } \\
\text { informal } \\
\text { finance }\end{array}$ \\
\hline Jinan & Mean & 1.825 & 5.429 & 94.929 & $61,577.78$ & 0.156 & 4.873 & 0.165 & 0.055 & 6.837 & 6.403 & 8.959 \\
\hline \multirow{2}{*}{ Qingdao } & Mean & 1.782 & 5.326 & 82.338 & $64,140.78$ & 0.167 & 4.371 & 0.223 & 0.054 & 6.997 & 8.312 & 17.357 \\
\hline & Std.Dev & 0.075 & 1.353 & 33.24 & $13,268.1$ & 0.241 & 0.152 & 0.398 & 0.147 & 0.947 & 0.242 & 0.621 \\
\hline \multirow{2}{*}{ Zibo } & Mean & 0.035 & 4.229 & 72.671 & $67,654.14$ & 0.596 & 1.503 & 0.264 & 0.361 & 7.621 & 6.991 & 8.495 \\
\hline & Std.Dev & 0.003 & 1.803 & 38.040 & 9387.51 & 0.026 & 0.018 & 0.227 & 0.376 & 0.611 & 0.216 & 0.689 \\
\hline \multirow{2}{*}{ Zaozhuang } & Mean & 0.770 & 1.857 & 72.571 & $25,675.00$ & 0.522 & 1.267 & 0.369 & 0.451 & 8.184 & 8.102 & 8.029 \\
\hline & Std.Dev & 0.031 & 0.541 & 20.313 & 5349.06 & 0.206 & 0.046 & 0.367 & 0.18 & 0.471 & 0.507 & 0.528 \\
\hline \multirow{2}{*}{ Dongying } & Mean & 2.563 & 4.097 & 69.429 & $65,412.77$ & 0.587 & 5.230 & 0.539 & 0.428 & 10.323 & 8.095 & 7.320 \\
\hline & Std.Dev & 0.293 & 0.401 & 14.593 & $22,231.21$ & 0.089 & 0.738 & 0.024 & 0.012 & 0.737 & 0.701 & 0.697 \\
\hline \multirow{2}{*}{ Yantai } & Mean & 1.763 & 3.961 & 47.529 & $35,087.57$ & 0.662 & 4.550 & 0.324 & 0.421 & 7.2 & 6.6 & 8.880 \\
\hline & Std.Dev & 0.324 & 0.754 & 6.024 & 7034.80 & 0.050 & 0.161 & 0.032 & 0.024 & 0.009 & 0.7 & 0.610 \\
\hline \multirow{2}{*}{ Weifang } & Mean & 1.511 & 1.993 & 102.286 & $27,851.71$ & 0.840 & 1.860 & 0.199 & 0.574 & 10.1 & 9.142 & 6.622 \\
\hline & Std.Dev & 0.055 & 0.719 & 56.680 & $12,778.82$ & 0.049 & 0.051 & 0.026 & 0.362 & 0.721 & 0.797 & 1.050 \\
\hline \multirow{2}{*}{ jining } & Mean & 1.097 & 1.954 & 60.971 & 8897.42 & 0.585 & 1.546 & 0.516 & 0.465 & 8.796 & 7.784 & 7.606 \\
\hline & Std.Dev & 0.120 & 0.871 & 28.370 & 803.534 & 0.057 & 0.055 & 0.012 & 0.045 & 0.489 & 0.375 & 0.602 \\
\hline Taian & Mean & 0.704 & 1.459 & 40.357 & 53211.16 & 0.479 & 1.353 & 0.289 & 0.455 & 7.777 & 7.810 & 8.446 \\
\hline \multirow{2}{*}{ Weihai } & Mean & 0.049 & 4.007 & 116.931 & $57,336.93$ & 0.606 & 2.848 & 0.198 & 0.390 & 8.1 & 7.1 & 8.545 \\
\hline & Std.Dev & 0.004 & 0.146 & 7.038 & $25,471.70$ & 0.020 & 0.441 & 0.036 & 0.009 & 0.5 & 0.004 & 0.490 \\
\hline \multirow{2}{*}{ Rizhao } & Mean & 1.207 & 2.099 & 62.400 & 30166.75 & 0.962 & 2.217 & 0.338 & 0.189 & 9.08 & 7.550 & 6.471 \\
\hline & Std.Dev & 0.120 & 0.561 & 28.453 & 8847.22 & 0.035 & 0.288 & 0.654 & 0.319 & 0.500 & 0.443 & 0.727 \\
\hline \multirow{2}{*}{ Laiwu } & Mean & 0.093 & 2.336 & 91.613 & $36,342.21$ & 0.912 & 2.083 & 0.260 & 0.214 & 9.324 & 7.865 & 7.581 \\
\hline & Std.Dev & 0.005 & 0.654 & 25.310 & $15,233.63$ & 0.021 & 0.164 & 0.039 & 0.019 & 0.576 & 0.544 & 0.488 \\
\hline \multirow{2}{*}{ Dezhou } & Mean & 1.361 & 1.722 & 67.214 & $27,552.70$ & 0.501 & 1.314 & 0.377 & 0.634 & 8.053 & 7.240 & 8.230 \\
\hline & Std.Dev & 0.178 & 0.795 & 26.975 & $12,174.30$ & 0.026 & 0.075 & 0.596 & 0.082 & 0.850 & 0.633 & 0.409 \\
\hline \multirow{2}{*}{ Linyi } & Mean & 1.012 & 1.756 & 33.864 & $13,113.39$ & 0.705 & 2.297 & 0.172 & 0.492 & 8.174 & 7.104 & 8.331 \\
\hline & Std.Dev & 0.099 & 0.929 & 22.759 & 4056.47 & 0.621 & 0.692 & 0.153 & 0.1 & 0.280 & 0.329 & 0.680 \\
\hline \multirow{2}{*}{ Liaocheng } & Mean & 1.002 & 1.736 & 70.693 & $24,067.31$ & 0.589 & 1.177 & 0.251 & 0.632 & 8.258 & 7.148 & 8.318 \\
\hline & Std.Dev & 0.037 & 0.875 & 28.187 & $11,121.44$ & 0.011 & 0.055 & 0.066 & 0.027 & 0.588 & 0.534 & 0.468 \\
\hline \multirow{2}{*}{ Binzhou } & Mean & 1.060 & 2.239 & 82.331 & $36,253.87$ & 0.734 & 2.157 & 0.265 & 0.724 & 9.3 & 7.4 & 8.1 \\
\hline & Std.Dev & 0.044 & 0.826 & 33.121 & $13,956.15$ & 0.549 & 0.228 & 0.481 & 0.106 & 0.8 & 0.5 & 0.273 \\
\hline \multirow{2}{*}{ Heze } & Mean & 0.519 & 1.264 & 20.279 & $19,046.28$ & 0.617 & 0.860 & 0.183 & 0.649 & 7.672 & 6.517 & 8.857 \\
\hline & Std.Dev & 0.122 & 0.295 & 3.920 & $10,067.79$ & 0.042 & 0.074 & 0.028 & 0.018 & 1.635 & 0.869 & 0.691 \\
\hline
\end{tabular}

Notes: All the Data are from Shandong Statistical Yearbook (2011-2017), Shandong Financial Yearbook (2011-2017) and the City Statistical Yearbook (2011-2017) of the 17 cities. 
J. H. Yi et al.

Table 3. The results of the three indexes (2010-2016).

(a)

\begin{tabular}{|c|c|c|c|c|c|c|c|c|c|c|}
\hline Index & Year & Jinan & Qingdao & Zibo & Zaozhuang & Dongying & Yantai & Weifang & Jining & Taian \\
\hline \multirow{8}{*}{$\begin{array}{l}\text { Index of Financial } \\
\text { Inclusion }\end{array}$} & 2010 & 0.035 & 0.099 & 0.010 & 0.022 & 0.030 & 0.082 & 0.005 & 0.021 & 0.013 \\
\hline & 2011 & 0.224 & 0.210 & 0.203 & 0.117 & 0.330 & 0.303 & 0.148 & 0.195 & 0.092 \\
\hline & 2012 & 0.420 & 0.451 & 0.411 & 0.280 & 0.508 & 0.352 & 0.368 & 0.335 & 0.163 \\
\hline & 2013 & 0.636 & 0.332 & 0.602 & 0.664 & 0.656 & 0.572 & 0.668 & 0.685 & 0.626 \\
\hline & 2014 & 0.744 & 0.547 & 0.771 & 0.795 & 0.763 & 0.459 & 0.845 & 0.857 & 0.817 \\
\hline & 2015 & 0.780 & 0.785 & 0.893 & 0.851 & 0.851 & 0.764 & 0.918 & 0.855 & 0.846 \\
\hline & 2016 & 0.820 & 0.953 & 0.915 & 0.888 & 0.889 & 0.977 & 0.977 & 0.855 & 0.853 \\
\hline & 2010 & 0.002 & 0.087 & 0.000 & 0.000 & 0.000 & 0.002 & 0.000 & 0.000 & 0.000 \\
\hline \multirow{5}{*}{$\begin{array}{l}\text { Coverage index of } \\
\text { financial service }\end{array}$} & 2011 & 0.197 & 0.108 & 0.202 & 0.090 & 0.335 & 0.243 & 0.126 & 0.171 & 0.072 \\
\hline & 2012 & 0.437 & 0.154 & 0.416 & 0.274 & 0.580 & 0.437 & 0.383 & 0.332 & 0.155 \\
\hline & 2013 & 0.716 & 0.307 & 0.620 & 0.730 & 0.748 & 0.701 & 0.687 & 0.718 & 0.666 \\
\hline & 2014 & 0.967 & 0.412 & 0.812 & 0.906 & 0.957 & 0.944 & 0.937 & 0.966 & 0.988 \\
\hline & 2015 & 0.924 & 0.854 & 0.953 & 0.981 & 0.981 & 0.987 & 0.981 & 0.971 & 0.965 \\
\hline \multirow{8}{*}{$\begin{array}{c}\text { Cost index of financial } \\
\text { service }\end{array}$} & 2016 & 0.889 & 0.997 & 0.974 & 0.942 & 0.993 & 0.971 & 0.989 & 0.979 & 0.940 \\
\hline & 2010 & 0.554 & 0.654 & 0.539 & 0.501 & 0.338 & 0.668 & 0.296 & 0.523 & 0.378 \\
\hline & 2011 & 0.785 & 0.504 & 0.272 & 0.834 & 0.680 & 0.632 & 0.718 & 0.689 & 0.629 \\
\hline & 2012 & 0.128 & 0.229 & 0.047 & 0.150 & 0.181 & 0.013 & 0.134 & 0.104 & 0.068 \\
\hline & 2013 & 0.184 & 0.314 & 0.287 & 0.169 & 0.317 & 0.261 & 0.607 & 0.278 & 0.156 \\
\hline & 2014 & 0.137 & 0.521 & 0.351 & 0.275 & 0.293 & 0.276 & 0.075 & 0.368 & 0.314 \\
\hline & 2015 & 0.351 & 0.658 & 0.488 & 0.437 & 0.583 & 0.461 & 0.283 & 0.589 & 0.497 \\
\hline & 2016 & 0.588 & 0.784 & 0.646 & 0.654 & 0.789 & 0.648 & 0.289 & 0.910 & 0.547 \\
\hline
\end{tabular}

(b)

\begin{tabular}{cccccccccccc}
\hline Index & Year & Weihai & Rizhao & Laiwu & Dezhou & Linyi & Liaocheng & Binzhou & Heze \\
\hline & 2010 & 0.018 & 0.042 & 0.022 & 0.016 & 0.004 & 0.011 & 0.011 & 0.094 \\
& 2011 & 0.227 & 0.363 & 0.212 & 0.148 & 0.072 & 0.158 & 0.169 & 0.208 \\
& 2012 & 0.522 & 0.532 & 0.499 & 0.400 & 0.263 & 0.424 & 0.485 & 0.407 \\
Index of Financial & 2013 & 0.660 & 0.618 & 0.649 & 0.667 & 0.589 & 0.706 & 0.691 & 0.534 \\
Inclusion & 2014 & 0.781 & 0.694 & 0.798 & 0.865 & 0.903 & 0.900 & 0.777 & 0.771 \\
& 2015 & 0.843 & 0.737 & 0.833 & 0.917 & 0.944 & 0.917 & 0.838 & 0.770 \\
& 2016 & 0.921 & 0.775 & 0.848 & 0.954 & 0.969 & 0.915 & 0.844 & 0.756 \\
& 2010 & 0.000 & 0.000 & 0.000 & 0.000 & 0.001 & 0.000 & 0.000 & 0.000 \\
& 2011 & 0.213 & 0.370 & 0.182 & 0.115 & 0.059 & 0.139 & 0.144 & 0.130 \\
Coverage index of & 2012 & 0.536 & 0.609 & 0.516 & 0.398 & 0.255 & 0.411 & 0.499 & 0.442 \\
financial service & 2013 & 0.780 & 0.842 & 0.721 & 0.683 & 0.608 & 0.727 & 0.711 & 0.706 \\
& 2014 & 0.967 & 0.937 & 0.907 & 0.907 & 0.960 & 0.971 & 0.834 & 0.901 \\
& 2015 & 0.983 & 0.977 & 0.964 & 0.964 & 0.970 & 0.973 & 0.845 & 0.946 \\
& 2016 & 0.979 & 0.992 & 1.000 & 1.000 & 0.982 & 0.941 & 0.855 & 0.970 \\
\hline
\end{tabular}




\section{Continued}

\begin{tabular}{|c|c|c|c|c|c|c|c|c|c|}
\hline \multirow{7}{*}{$\begin{array}{c}\text { Cost index of financial } \\
\text { service }\end{array}$} & 2010 & 0.487 & 0.397 & 0.491 & 0.649 & 0.363 & 0.609 & 0.343 & 0.648 \\
\hline & 2011 & 0.763 & 0.795 & 0.657 & 0.878 & 0.662 & 0.941 & 0.427 & 0.578 \\
\hline & 2012 & 0.000 & 0.106 & 0.000 & 0.044 & 0.026 & 0.124 & 0.330 & 0.152 \\
\hline & 2013 & 0.379 & 0.422 & 0.254 & 0.279 & 0.314 & 0.123 & 0.203 & 0.048 \\
\hline & 2014 & 0.412 & 0.380 & 0.486 & 0.474 & 0.394 & 0.399 & 0.194 & 0.712 \\
\hline & 2015 & 0.345 & 0.590 & 0.534 & 0.708 & 0.576 & 0.568 & 0.700 & 0.796 \\
\hline & 2016 & 0.676 & 0.894 & 0.781 & 0.839 & 0.781 & 0.777 & 1.000 & 0.934 \\
\hline
\end{tabular}

Notes: All the Data are from our survey. Because of the authorization clause, we could not provide the original data to any company and individual, but can use the data for theoretical study and publish the results.

where $I F D I_{i}$ denotes the overall IFI; corporate and $\triangle$ capital denote the number of micro-credit organizations $s^{5}$ and the increase rate of registered capital, respectively, both reflecting the scale of development of micro-credit organizations; $\Delta$ loan and $\Delta$ custom denote the increase rates of loans and customers, respectively, both reflecting the supply capacity of financial service; $r_{\text {loan }}$ denotes the loan interest rate and reflects the cost of the financial service; $R_{N P L S}$ and $g_{\text {profit }}$ denote the non-performing loan (NPL) ratio of micro-credit organizations and the increase rate of profit, respectively, both reflecting their performance and risk; $P_{\text {loan }}<50$ denotes the proportion of customers with the single account balance less than RMB 500,000: since China's micro-credit organizations are still at the policy-driven stage and undertake necessary policy functions at present, this paper select the "Proportion of customers with the single account balance no more than RMB 500,000" as the control variable which can reflect the realization of policy goals. $\alpha$ and $\beta_{i}$ are the coefficients to be estimated. $u_{i}+\varepsilon_{i t}$ is the compound disturbance term, in which $u_{i}$ is the intercept term reflecting the individual heterogeneity and $\varepsilon_{i t}$ is the disturbance term.

\subsection{Empirical Results}

We first perform the Hausman test to pick the appropriate estimation method. It turns out that the F-statistics is 58.53 with a p-value of zero. Therefore we pick the fixed effects model and report the estimation results in Table 4.

To check the stability of our model, this paper adopts LLC Test and MV Test to analyze the residual of the above regression. The P-values of these Tests are 0.08 and 0.07 , respectively, showing that the model's residual is stationary.

From Table 4 we obtain several findings. First, there is a significantly positive correlation between corporate and $I F D I_{i}$, suggesting that expanding the scale of micro-credit organizations has a positive influence on the development of financial inclusion. The main reason is because the micro-credit organizations complements the traditional commercial financial institutions along the initial development of financial inclusion. This complementarity accelerates the development of microcredit and decreases the threshold of low income individuals to ${ }^{5}$ In order to reflect the difference in development scale of micro-credit organizations across prefectures , this paper considers the number of micro-credit organizations in the model. 
Table 4. The regression results of model I.

\begin{tabular}{cccc}
\hline Variable & Coefficients & z statistics & P value \\
\hline corporate & 0.017 & 4.37 & $0^{* * *}$ \\
$\Delta$ capital & -0.193 & -0.79 & 0.442 \\
$g_{\text {proft }}$ & 0.002 & 0.13 & 0.9 \\
$\Delta$ loan & 0.001 & 2.14 & $0.048^{* *}$ \\
$r_{\text {loan }}$ & -2.63 & -2.89 & $0.011^{\star *}$ \\
$R_{\text {NPLs }}$ & -1.83 & -2.01 & $0.061^{*}$ \\
$\Delta$ custom & 0.022 & 2.66 & $0.017^{* *}$ \\
$P_{\text {loan }}<50$ & 0.77 & 6.82 & $0^{* * *}$ \\
$\alpha$ & 0.858 & 5.68 & $0^{* * *}$ \\
\hline
\end{tabular}

Notes: This table presents the results of fixed effect model for the time period from 2009 to 2015 . ***, ${ }^{*}$ and $^{*}$ denote the statistical significance at levels of $1 \%, 5 \%$, and $10 \%$ respectively.

receive various financial services. Second, the coefficients of $g_{\text {profit }}$ and $I F D I_{i}$ are not statistically significant at the level of $10 \%$, indicating that the internal operation of micro-credit organizations are not able to affect the whole financial market at the initial stage of financial inclusion ${ }^{6}$. Third, there are significantly positive correlations among $\Delta$ custom, $\Delta$ loan and $I F D I_{i}$, showing a positive influence on the development of financial inclusion when the micro-credit organizations increase the scale of credit and expand their customers. This finding is consistent with existing studies on micro-credit. Fourth, there is a significantly negative correlation between $r_{\text {loan }}$ and $I F D I_{i}$. Decreasing the loan rate will promote the development of financial inclusion. This is consistent with the goal of "providing quality financial services at the affordable cost". When the loan rate of micro-credit organizations is lower, the customer will obtain financial services with a lower cost. Fifth, there is a significantly negative correlation between $R_{N P L s}$ and $I F D I_{i}$, which indicates that the current operation risks of micro-credit organizations can affect the financial market. In particular, under the background of China's economic slowdown and increasing exposure of regional financial risks, financial market's vulnerability gradually increases. When the NPL increases rapidly, it increases market friction, raises market threshold, and impedes the development of financial inclusion.

To summarize, the existence of micro-credit organizations has a positive influence on the development of financial inclusion. By establishing new institutions, increasing loans at reasonable interest rate level and attracting more customers, micro-credit organizations play a role in improving the access of financial services and lowering the entry cost. In the next section, we will further explore the nature of financial inclusion and investigate whether the micro-credit organizations are able to expand financial service coverage and lower the financial service costs.

${ }^{6}$ There is another possibility. The indicators selected to establish the index of financial inclusion in the paper mainly reflect the changes of financial supply capacity, while the influence of the small-loan companies' internal operation conditions on the rural financial supply is not clear yet. 


\section{The Influence on the Coverage and Cost of Financial Services}

The notion of inclusive finance includes two key components: to expand the coverage of financial service and to reduce the cost of financial service (Beck et al. 2007). In what follows, we further check the impacts of micro-credit on the Coverage index and the Cost index of financial service.

\subsection{The Study on the Coverage Index of Financial Service}

The model II specification is similar:

$$
\begin{gathered}
\operatorname{IFDI}_{i}^{\prime}=\alpha^{\prime}+\beta_{i}^{\prime} T_{i t}^{\prime}+u_{i}^{\prime}+\varepsilon_{i t}^{\prime} \\
T_{i t}^{\prime}=\left(\text { corporate, } \Delta \text { capital, } g_{\text {profit }}, R_{N P L s}, P_{\text {loan }}<50, \Delta \text { custom }_{A}, \Delta \text { custom }_{B}\right)_{i t}
\end{gathered}
$$

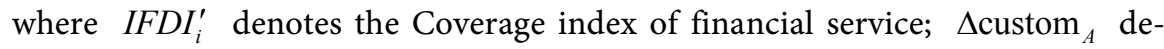
notes the growth rate of agriculture-related customers; $\Delta$ custom $_{B}$ denotes the growth rate of micro business customers; other variables share the same meanings as before.

The F-statistics of the Hausman Test is 59.53 with a p-value close to zero, lending support to a fixed effects model. The estimation results are reported in Table 5.

Table 5 includes the following findings. First, there is a significantly positive correlation between corporate and $I F D I_{i}^{\prime}$, suggesting that expanding the scale of micro-credit organizations generates a positive influence on the coverage of financial service. The main reason is that because of a lower return and higher information asymmetry, the formal and large commercial financial institutions are reluctant to increase the services in the county or rural areas; micro-credit organizations, as local creditors of micro loans, can effectively fill the blank left by the large financial institutions in rural area. Second, there is a significantly positive correlation among $P_{\text {loan }}<50, \Delta$ custom $_{A}$ and $I F D I_{i}^{\prime}$, but no significant correlation between $\Delta \operatorname{custom}_{B}$ and $I F D I_{i}^{\prime}$. It indicates that increasing

Table 5. The regression results of Model II.

\begin{tabular}{cccc}
\hline Variable & Coefficients & z statistics & P value \\
\hline corporate & 0.019 & 3.53 & $0.003^{* * *}$ \\
$\Delta$ capital & -0.014 & -1 & 0.334 \\
$g_{\text {profit }}$ & 0.007 & 2.42 & $0.028^{* *}$ \\
$R_{\text {NPLs }}$ & -2.31 & 2.23 & $0.04^{* *}$ \\
$P_{\text {loan }}<50$ & 0.943 & 5.99 & $0^{* * *}$ \\
$\Delta$ custom $_{A}$ & 0.007 & 2.92 & $0.01^{* *}$ \\
$\Delta$ custom $_{B}$ & 0.003 & 0.29 & 0.774 \\
$\alpha$ & 0.525 & 4.67 & $0^{* * *}$
\end{tabular}

Notes: This table presents the results of fixed effect model. ${ }^{* * *},{ }^{* *}$ and ${ }^{*}$ denote the statistical significance at levels of $1 \%, 5 \%$, and $10 \%$ respectively. 
loans to agriculture-related customers can expand the coverage of financial service, but increasing loans to micro business customers cannot. The main reason is because the total capital of micro-credit organizations is limited in rural area. If they focus on the micro business customers that needs more loans, the number of the customers cannot increase a lot; meanwhile, micro-credit organizations will have to compete with other financial institutions for lending to micro business customers. This will also weaken its improvement on financial service coverage. However, if they focus on agriculture-related customers (individual farmers in most cases), the number of customers will increase greatly, complementing other financial institutions and improving the coverage of financial services. Third, there is a significantly positive correlation between $g_{\text {profit }}$ and $I F D I_{i}^{\prime}$, implying that increasing the profit of micro-credit organizations helps to improve the coverage of financial services.

\subsection{The Study on the Coverage Index of Financial Service Cost}

The Model III is specified as:

$$
\begin{gathered}
I F D I_{i}^{\prime \prime}=\alpha^{\prime \prime}+\beta_{i}^{\prime \prime} T_{i t}^{\prime \prime}+u_{i}^{\prime \prime}+\varepsilon_{i t}^{\prime \prime} \\
T_{i t}^{\prime \prime}=\left(\text { corporate }, \Delta \text { capital }, g_{\text {proffi }}, r_{\text {loan }}, R_{N P L s}, P_{\text {loan }}<50, P_{\text {loan }_{s}}\right)_{i t}
\end{gathered}
$$

where IFDI" denotes the Coverage index of financial service cost; $P_{\text {loan }}$ denotes the proportion of short-term loan; other variables share the same meanings as before.

The F-statistics of the Hausman test becomes 24.72 with a p-value of 0.001 . The fixed effects model is estimated and the results are reported in Table 6.

Table 6 reports the following major findings. First, there is a significantly positive correlation between $I F D I_{i}^{\prime \prime}$ and $g_{\text {profit }}$; the increasing profit of the micro-credit organizations has a positive effect on reducing the cost of financial services. This is because, when profit increases, the micro-credit organizations gradually improve upon capital operation and risk management. Meanwhile, they are able to increase innovation and expand the market so as to consolidate the foundation of future growth. In other words, the micro-credit organizations enter a positive feedback loop --increasing profit $\rightarrow$ improved internal management $\rightarrow$ reduced cost and expanding market $\rightarrow$ increasing further profit. This finding is consistent with the regression coefficient of $R_{N P L S}$ : a negative correlation between $I F D I_{i}^{\prime \prime}$ and $R_{N P L S}$. When the risk of micro-credit organizations is high, the index of financial services cost is low and the cost of financial services is high. By combining these two variables, we find a close relation between the stability and profitability of micro-credit organizations and reducing financial service costs. Second, there is a significantly negative correlation between $I F D I_{i}^{\prime \prime}$ and $r_{\text {loan }}$. This means a decreasing loan interest rate of micro-credit organizations can help reduce the financial service cost. This finding complies with conventional financial theory. Third, there is a significantly positive correlation between IFDI" and $P_{\text {loan }_{\mathrm{s}}}$. It shows that increasing the proportion of 
Table 6. The regression results of Model III.

\begin{tabular}{cccc}
\hline Variable & Regression coefficients & $\mathrm{z}$ statistics & P value \\
\hline corporate & 0.001 & 0.22 & 0.831 \\
$\Delta$ capital & 0.021 & 0.99 & 0.337 \\
$g_{\text {profit }}$ & 0.012 & 5.63 & $0^{* * *}$ \\
$r_{\text {loan }}$ & -7.99 & -7.61 & $0^{* * *}$ \\
$R_{\text {NPLs }}$ & -2.701 & -1.93 & $0.072^{*}$ \\
$P_{\text {loan }}<50$ & 0.218 & 1.29 & 0.215 \\
$P_{\text {loans }}$ & 0.037 & 1.64 & $0.093^{\star}$ \\
$\alpha^{\prime \prime \prime}$ & 1.45 & 5.99 & 0 \\
\hline
\end{tabular}

Note: 1 . This table presents the results of Fixed effect model. ${ }^{\star * *},{ }^{\star *}$ and $^{\star}$ denote the statistical significance at levels of $1 \%, 5 \%$, and $10 \%$ respectively.

short-term loans of micro-credit organizations can help to reduce the cost of financial services. The result is closely related to the origin of micro-credit organizations in China: in regional financial market, micro-credit organizations have more advantages in providing short-term loans. On the one hand, compared with informal finance such as private lending, the interest rate of micro-credit organizations is relatively low, and the cost advantage is obvious; on the other hand, compared with the formal finance such as commercial banks and rural credit cooperatives, the short-term lending through micro-credit organizations is relatively flexible. Therefore increasing the proportion of short-term loans of micro-credit organizations can help meet more demand for short-term capital of different enterprises, reduce the lending from informal finance, and effectively reduce the cost of financial services.

To summarize, the existence of micro-credit organizations has a positive influence on reducing the cost of financial services and increasing the coverage of the financial services. It provides significant evidence that the micro-credit organizations are able to make the financial service more available and affordable, and cause the same effect to the development of financial inclusion.

\section{Conclusion}

To sum up, scale expansion, internal management improvement, and credit expansion all produce positive impacts on the development of inclusive finance. As for the mechanism, increasing the supply of funds is the key to fill in the "gap" between the supply of and the demand for financial services. Following the nature of inclusive finance, this paper further carried out empirical research on whether development of micro-credit organizations is helpful to improve the coverage of financial services and to reduce the financial service cost. The empirical results in this paper show that the improved management of micro-credit organizations (e.g., expansion of scale, increasing the proportion of short-term loans, decreasing the loan interest rate, etc.) can help improve the coverage of 
financial services and reduce the financial service cost, confirming the positive effect on the overall development of inclusive finance. Meanwhile, we also found the difference of the effects of the increase rate of registered capital, non-performing loan ratio and other variables on each sub-index. This illustrates the uncertain effects of these factors on the development of inclusive finance and motivates future research questions in this field. Moreover, because of the large geographical area, there are significant variations across different regions regarding poor population distribution and natural endowments in China. How to take into account the impacts of geography and natural factors on the interaction between inclusive finance and micro-credit organizations is also left for future research.

\section{Acknowledgements}

We greatly appreciate the financial support of National Natural Science Foundation of China (71333009, 71273155, and 71503147) and the Special Fund of Shandong Social Science Foundation (16BJRJ01).

\section{Conflicts of Interest}

The authors declare no conflicts of interest regarding the publication of this paper.

\section{References}

Allen, F., Demirguc-Kunt, A., Klapper, L., \& Martinez Peria, M. S. (2016). The Foundations of Financial Inclusion: Understanding Ownership and Use of Formal Accounts. Journal of Financial Intermediation, 27, 1-30. https://doi.org/10.1016/j.jfi.2015.12.003

Beck, T., Demirguc-Kunt, A., \& Martinez Peria, M. S. (2007). Reaching out: Access to and Use of Banking Services across Countries. Journal of Financial Economics, 85, 234-266. https://doi.org/10.1016/j.jfineco.2006.07.002

Branch, B., \& Cifuentes, M. (2001). The Road to Jinotega. Part II: Towards Maximising Credit Union Financial Sustainability. Madison: World Council of Credit Unions.

Bruhn, M., \& Love, I. (2014). The Real Impact of Improved Access to Finance: Evidence from Mexico. Journal of Finance, 69, 1347-1376. https://doi.org/10.1111/jofi.12091

Dayson, K., Paterson, B., \& Conaty, P. (2001). Investing in People and Land. Cheltenham, United Kingdom: Countryside Agency, Salford, United Kingdom: Community Finance Solutions.

Global Partnership for Financial Inclusion (GPFI) (2015). http://www.gpfi.org/publications

Jones, P. A. (1999). Towards Sustainable Credit Union Development. Manchester: ABCUL.

Jones, P. A. (2001). Growth of Credit Unions and Credit Co-Operatives: Is the Past Still Present? In G. Christophe, \& M. Edward (Eds.), Banking and Social Cohesion (pp.100-108). Charlbury: Jon Carpenter Publishing.

Jones, P. A. (2006). Giving Credit Where It's due: Promoting Financial Inclusion through Quality Credit Unions. Local Economy, 21, 36-48. https://doi.org/10.1080/02690940500504814

Levine, R. (1999). Law Finance and Economic Growth. Journal of Financial Intermedia- 
tion, 8, 8-35. https://doi.org/10.1006/jfin.1998.0255

Lusardi, A. (2010). American's Financial Capability. Report Prepared for the United States Government Financial Crisis Inquiry Committee (FCIC).

McKillop, D. G., Ward, A. M., \& Wilson, L. O. S. (2007). The Development of Credit Unions and Their Role in Tackling Financial Inclusion. Public Money and Management, 27, 37-44. https://doi.org/10.1111/j.1467-9302.2007.00553.x

Palmer, G., \& Conaty, P. (2002). Profiting from Poverty. London: New Economics Foundation.

Vighneswara, S. (2014). Financial Inclusion, Gender Dimension, and Economic Impact on Poor Households. World Development, 55, 1-15.

Zuzana, F., \& Laurent, W. (2015). Understanding Financial Inclusion in China. China Economic Review, 34, 196-206. https://doi.org/10.1016/j.chieco.2014.12.004 